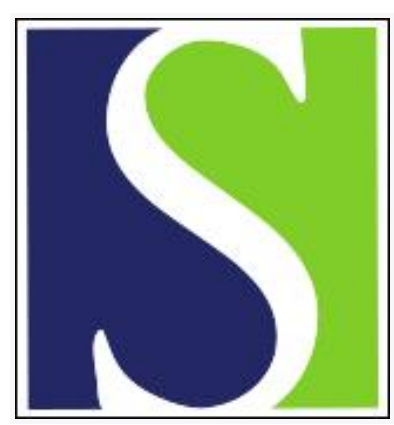

Scand J Work Environ Health 2003;29(2):100-105

https://doi.org/10.5271/sjweh.711

Issue date: Apr 2003

Cancer incidence among Icelandic deck officers in a population-based study

by Sulem P, Rafnsson V

Affiliation: Department of Preventive Medicine, University of Iceland, Soltun 1, 105 Reykjavik, Iceland.

Key terms: bladder neoplasm; cancer incidence; deck officer; electromagnetic fields; Iceland; population-based study; smoking; soft tissue sarcoma; testis neoplasm

This article in PubMed: www.ncbi.nlm.nih.gov/pubmed/12718495

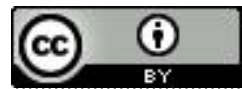




\title{
Cancer incidence among Icelandic deck officers in a population-based study
}

\author{
by Patrick Sulem, MD, ${ }^{1}$ Vilhjálmur Rafnsson, $M D^{1}$
}

\begin{abstract}
Sulem P, Rafnsson V. Cancer incidence among Icelandic deck officers in a population-based study. Scand J Work Environ Health 2003;29(2):100-105.
\end{abstract}

\begin{abstract}
Objectives The aim of this study was to define the cancer pattern in an Icelandic cohort of deck officers while indirectly controlling for their smoking habits.

Methods A cohort of 3874 male deck officers was followed from 1966 to 1998. It was record-linked by the deck officers' personal identification numbers to population-based registers containing each person's vital and emigration status and cancer diagnosis. Standardized incidence ratios (SIR) were calculated for all cancers and different cancer sites in relation to different lag times and years of birth. Information on smoking habits was obtained by from a questionnaire administered to a sample of the cohort $(\mathrm{N}=728)$.

Results In the total cohort 436 cancers were observed, equal to the expected 436 [SIR 1.0, 95\% confidence interval (95\% CI) 0.9-1.1], and a significantly increased risk of soft-tissue sarcoma (SIR 2.7, 95\% CI 1.2-5.1) was found together with a decreased risk of testis cancer (SIR 0.0, 95\% CI $\cdots-0.7$ ) and urinary bladder cancer (SIR 0.5, 95\% CI 0.3-0.8). The deck officers' smoking habits were similar to those found in a sample of the general population. The predictive value was 1.11 for lung cancer and 1.04 for bladder cancer.

Conclusions An increased incidence of soft-tissue sarcoma was found among deck officers. This increase resembles that previously found for Swedish deck officers, and it warrants further study.
\end{abstract}

Key terms bladder neoplasm, electromagnetic fields, smoking, soft tissue sarcoma, testis neoplasm.

In a previous study on cancer incidence among Icelandic seamen, it was not possible to differentiate between the cancer risk of subordinates and officers (1). The results indicated an increased risk of all cancers, larynx cancer, stomach cancer, and lung cancer (1). Scandinavian studies dealing with cancer risk among deck officers in particular have shown an increased risk of all cancers $(2,3)$, lung cancer and larynx cancer (3), nonmelanoma skin cancer $(3,4)$, kidney and brain cancer (4), and soft-tissue sarcoma (3).

In general, deck officers are not assumed to be especially exposed to dangerous chemicals. Cancer risk among Norwegian mates has been shown to be related, however, to chemical exposure on oil tankers (5) in a case-referent study. A lung cancer risk among deck officers has not been attributed to asbestos exposure (3); however, a sequel of asbestos exposure has frequently been found among seamen (6-8), especially among marine engineers $(9,10)$.
The occupational environment of deck officers includes many electronic devices: computers, video display units, navigation instruments of different types, radar, and radio transmitters. Occupational exposure to electromagnetic fields and radiofrequency fields has, in previous studies, been related to the risk of leukemia and brain cancer (11).

The aim of this study was to define the cancer pattern in an Icelandic cohort of deck officers while indirectly controlling for smoking habits.

\section{Subjects and methods}

Information on Icelandic deck officers was obtained from a computerized file of graduates identical with a list of graduates in a book published on the occasion of the centenary of the Navigation School in Reykjavik (12). 
The register included all men who had graduated from the Navigation School up to 1991, and all men who were born in 1900 or later and were alive and resident in Iceland in 1966 were entered into the cohort $(\mathrm{N}=3874$ men). The Navigation School, established in 1891, is the only institute in the country that has graduated deck officers. There were four women in the register, but, as this number was considered too small for epidemiologic study, they were omitted.

The Navigation School requires that applicants have 2 years of practical experience as ordinary seamen before admission and that they are at least 18 years of age. The Navigation School offers the apprentices different courses of study, which, after a further period of practical training, qualifies them as mates and captains on fishing vessels of various sizes, on cargo and passenger vessels, and on coast guard ships. The School requires those accepted to be in good general health and to have intact sight and hearing ability.

After graduation, most of the men are employed as captains or mates on vessels of the comparatively large Icelandic fishing fleet and on freight vessels, passenger vessels, or other types of vessels. The total number of registered decked vessels in Iceland has increased from 870 in 1966 to 1014 in 2000 (13; also see http:// www.sigling.is/enska/ships.html). According to the register of ships in 1966, approximately $91 \%$ of the decked vessels were fishing vessels, while in $2000,83 \%$ were fishing vessels. Approximately $66 \%$ of the decked fishing vessels comprised less than 100 gross tonnage, but the largest had more than 1500 gross tonnage. In addition to these vessels, there were 455 open motorized boats in 1977 and 1134 in the year 2000 .

In their occupational environment, deck officers work in close proximity with electronic devices, computers, video display units, navigation instruments of different types, and radar and radio transmitters. Since the end of World War II, technical development has been quick, particularly during the 1950s, and, according to comments made in the questionnaire survey, the amount of instrumentation has been growing in importance for the bridge of fishing vessels of all types and sizes. Deck officers use this equipment and are exposed to their electromagnetic fields as bystanders. Currently no quantification of the exposure to these phenomena in the work environment of deck officers on board Icelandic vessels is available. According to questionnaire comments, exposure to these different electronic devices is a matter of concern to the officers.

Since 1951, all residents of Iceland have had a unique personal identification number that is used in population registries. The identification number of each subject was used in record linkage to the National Register and the Register of Deaths. In this manner vital and emigration status was ascertained for all of the subjects.
In this retrospective cohort study, the follow-up for cancer was carried out through record linkage with the Icelandic Cancer Register, which is a nationwide register of cancer cases, with over $95 \%$ histological verification, and the register is considered complete for all cancer cases in the country (14). The follow-up for cancer began the year of the person's graduation according to the register of the Navigation School or in 1966, the first year of the study, whichever came later. The follow-up ended at death $(\mathrm{N}=917)$, at emigration $(\mathrm{N}=60)$, or at the end of 1998, the last year of the follow-up period, whichever occurred first (15). The number of expected cancers was calculated on the basis of personyears for each 5-year age category and the cancer incidence rates for the male population in Iceland, obtained from the Icelandic Cancer Register. The ratio between the observed and expected numbers of cancers [ie, the standardized incidence ratio (SIR)] was calculated with its $95 \%$ confidence interval $(95 \% \mathrm{CI})$ on the assumption of Poisson distribution and with the use of Byar's approximation (15).

Separate analyses were also performed according to the year of birth and the level of education completed and with the use of a 20-year lag time. The lag time corresponded to the number of years allowed to elapse before the counting of person-years started. When a significantly increased standardized incidence ratio for a specific cancer site was determined, the patients were described regarding location, histological type, age at diagnosis, survival, and time interval from graduation to cancer diagnosis.

A survey of smoking habits, duration of work at sea, and different occupations (ordinary seamen, mate, and captain) was carried out in 2000 with the use of a questionnaire sent to active and retired members of the union of deck officers. In the survey, $66.0 \%$ of the total union group $(\mathrm{N}=1680)$ responded. Those who had graduated from the Navigation School, and thus qualified to be included in the cohort, were not all members of the union of deck officers. Of the participants in the questionnaire survey, 728 were members of the cohort. Partial nonresponse was less than $1.5 \%$. The items from the questionnaire are shown in tables 1 and 2.

The smoking habits revealed in this study were compared with the smoking habits of the general population, as indicated by the results of the same questionnaire used in the year 2000 by the Committee for Tobacco Use Prevention (16). The method introduced by Axelson \& Steenland (17) was used to assess the effect of tobacco smoking in the evaluation of possible confounding due to smoking. In this manner, the predictive value of lung cancer was calculated on the basis of the risk of lung cancer, which was assumed to be 1 for nonsmokers, 5 for ex-smokers, and 10 for current smokers. Similarly, the predictive value of bladder cancer was 
Table 1. Type and duration of occupations according to the questionnaire survey of deck officers $(\mathrm{N}=728)$ in 2000.

\begin{tabular}{lll}
\hline & $\mathrm{N}$ & $\%$ \\
\cline { 2 - 3 } & & \\
Ordinary seamen & 680 & 93 \\
$\geq 1$ year & 530 & 73 \\
$\geq 5$ years & & \\
Mate & 699 & 96 \\
$\geq 1$ year & 106 & 15 \\
$\geq 20$ years & & \\
Captain & 600 & 82 \\
$\geq 1$ year & 140 & 19 \\
$\geq 20$ years & \\
\hline
\end{tabular}

Table 2. Smoking habits of a random sample of the Icelandic male population $(\mathrm{N}=1118)$ and a sample of deck officers $(\mathrm{N}=728)$, age range $20-89$ years.

\begin{tabular}{lrrrrrr}
\hline & \multicolumn{2}{c}{ Population sample } & & \multicolumn{2}{c}{ Deck officers } \\
\cline { 2 - 3 } \cline { 6 - 7 } Smoking characteristic & \multicolumn{1}{c}{ N } & $\%$ & & $\mathrm{~N}$ & $\%$ \\
\hline Never smoked & 446 & 39.9 & & 185 & 25.4 \\
Stopped smoking >1 year ago & 291 & 26.0 & & 297 & 40.9 \\
Stopped smoking <1 year ago & 61 & 5.5 & & 49 & 6.7 \\
Smoker, not daily & 49 & 4.4 & & 21 & 2.9 \\
Smoker, daily & 271 & 24.2 & & 175 & 24.1 \\
\hline
\end{tabular}

calculated on the basis of the risk of bladder cancer, which was assumed to be 1 for nonsmokers, 1.5 for exsmokers, and 3 for current smokers.

The National Bioethics Committee and the Data Protection Commission approved the study.

\section{Results}

There were 3874 men followed in the cohort. The total number of person-years was 93715 . Altogether 728 men in the questionnaire survey on smoking habits were members of the cohort, and there was information available on the duration of work as seamen for $18.8 \%$ of the cohort. More than $96 \%$ reported having worked at least 1 year as a mate, and $82 \%$ had worked as a captain at least 1 year (table 1). The mean age at the time of the cancer diagnosis was 65 years, and the mean year of the diagnosis was 1988.

Table 3 shows the observed and expected numbers of cancer cases, the standardized incidence ratios, and the $95 \%$ confidence intervals for all cancers and selected cancer sites. During the follow-up period, 436 cancers were diagnosed in the whole cohort versus 436.30 expected. The observed number of soft-tissue sarcomas totaled 9 versus 3.33 expected (SIR 2.7, 95\% CI 1.25.1). Lung cancer incidence was increased, although not significantly (SIR 1.2, 95\% CI 0.9-1.5). No pleural cancers were observed. The standardized incidence ratios
Table 3. Observed and expected numbers of cancers and their standardized incidence ratios (SIR) and 95\% confidence intervals $(95 \% \mathrm{Cl})$ for the deck officers (93 715.5 person-years) in 1966-1998. (Statistically significant figures are shown in bold face.)

\begin{tabular}{lrrrr}
\hline Cancer site $^{\text {a }}$ & $\begin{array}{c}\text { Observed } \\
\text { (N) }\end{array}$ & $\begin{array}{c}\text { Expected } \\
\text { (N) }\end{array}$ & SIR & 95\% Cl \\
\hline Lip (140) & 3 & 4.45 & 0.7 & $0.1-2.0$ \\
Oral cavity (143-144) & 1 & 1.73 & 0.6 & $0.0-3.2$ \\
Pharynx (145-149) & - & 2.24 & 0.0 &..-1.6 \\
Esophagus (150) & 7 & 8.02 & 0.9 & $0.3-1.8$ \\
Stomach (151) & 42 & 40.27 & 1.0 & $0.8-1.4$ \\
Colon (153) & 32 & 31.90 & 1.0 & $0.7-1.4$ \\
Rectum (154) & 11 & 11.37 & 1.0 & $0.5-1.7$ \\
Liver (155) & 6 & 6.98 & 0.9 & $0.3-1.9$ \\
Pancreas (157) & 17 & 13.03 & 1.3 & $0.8-2.1$ \\
Larynx (161) & 6 & 5.46 & 1.1 & $0.4-2.4$ \\
Lung (162) & 67 & 56.70 & 1.2 & $0.9-1.5$ \\
Prostate (177) & 103 & 92.09 & 1.1 & $0.9-1.4$ \\
Testis (178) & - & 5.54 & $\mathbf{0 . 0}$ &.. \\
Kidney (180) & 28 & 23.65 & 1.2 & $0.8-1.7$ \\
Other urinary organs (181) & 16 & 31.28 & $\mathbf{0 . 5}$ & $\mathbf{0 . 3}-\mathbf{0 . 8}$ \\
Melanoma of skin (190) & 5 & 6.67 & 0.7 & $0.2-1.7$ \\
Other skin (191) & 14 & 11.37 & 1.2 & $0.7-2.1$ \\
Brain (193) & 13 & 14.33 & 0.9 & $0.5-1.6$ \\
Thyroid gland (194) & 12 & 9.74 & 1.2 & $0.6-2.2$ \\
Soft tissue sarcoma (197) & 9 & 3.33 & $\mathbf{2 . 7}$ & $\mathbf{1 . 2}-\mathbf{5 . 1}$ \\
Unspecified sites (199) & 7 & 9.47 & 0.7 & $0.3-1.5$ \\
Hodgkin's disease (201) & 2 & 3.15 & 0.6 & $0.1-2.3$ \\
Non-Hodgkin's lymphoma & 6 & 12.30 & 0.5 & $0.2-1.1$ \\
(200, 202) & & & & \\
Multiple myeloma (203) & 4 & 5.64 & 0.7 & $0.2-1.8$ \\
Leukemia (204) & 9 & 9.72 & 0.9 & $0.4-1.8$ \\
Other sites & 16 & 15.87 & 1.0 & $0.6-1.6$ \\
\hline All cancers (140-205) & 436 & 436.30 & 1.0 & $0.9-1.1$ \\
& & & & \\
\hline
\end{tabular}

a Code of the International Classification of Diseases (7th revision) in parentheses.

for testis cancer (SIR 0.0) and bladder cancer (other urinary organs) (SIR 0.5) were significantly decreased. A nonsignificant deficit of non-Hodgkin's lymphoma was also found (SIR 0.5). When a 20-year lag time was applied, the standardized incidence ratio for soft-tissue sarcoma was 2.2 (95\% CI 0.7-5.1) on the basis of five cases versus 2.27 expected (table 4 , on page 103).

Among those born in 1920 and earlier (table 5, on page 104) there was no significant deficit or excess for all cancers or selected cancer sites. The incidence of colon cancer was not significantly increased in this analysis (SIR 1.4, 95\% CI 0.9-2.1). Among the deck officers born in 1921 and later (table 5, on page 104), there was a significantly increased incidence of soft-tissue sarcoma (SIR 2.7) and a significantly decreased incidence of testis cancer (SIR 0.0) and bladder cancer (SIR 0.4). When the deck officers were divided into three groups according to the different levels of education, the patterns of cancer incidence were similar to those of the total cohort. 
Of the nine cases of soft-tissue sarcoma, seven were located in the trunk, and two were found in the lower limbs, according to the fourth digit of the International Classification of Diseases, 7 th revision. The soft-tissue sarcomas were of seven histopathologicqal types. Three were rhabdomyosarcomas, and there was one each of angiosarcoma, leiomyosarcoma, liposarcoma, myxoid liposarcoma, synovial sarcoma, and sarcoma not otherwise specified. The median age of the officers at the time of diagnosis of the soft-tissue sarcoma was 44 (range 24-75) years. The survival after the diagnosis was less than 5 years in six of the nine cases. Factors such as year of birth, year of graduation, place of birth, and graduation level did not show any particular pattern. The median period between the years of first graduation until the year of diagnosis of soft-tissue sarcoma was 20 (range 4-49) years.

The smoking habits, indicated by the questionnaire, were compared with those of a sample of the male population. Never smokers were not as frequent among the deck officers as among the general population; in contrast, the deck officers had stopped smoking more often (table 2). According to the method used by Axelson \& Steenland, the predictive value for lung and bladder cancer was 1.11 and 1.04 , respectively, for the deck officers.

\section{Discussion}

This study did not show an increased risk of all cancers among deck officers. On the other hand, an increased risk of soft-tissue sarcoma and decreased risks of bladder cancer and testis cancer were found. Differences in smoking habits may partly explain the nonsignificant increased risk of lung cancer. However, a significantly decreased risk of bladder cancer was found in spite of a higher frequency of smokers among the deck officers. The evaluation of the role of smoking habits on the cancer risk in our study is an advantage over previous studies on deck officers, in which the information on smoking has been limited (2-4).

To our knowledge, according to the number of person-years, our cohort study of deck officers is the largest published for this occupational category thus far. The strength of the study is the use of the comprehensive population registers in Iceland, particularly the Icelandic Cancer Register. The universal use of the personal identification numbers made record linkage possible, and thus also the ascertainment of vital status for all cohort members and the complete identification of cancers in the nationwide cancer register. The cancer incidence rates for the male population were also obtained from the cancer register; thus the source of information
Table 4. Observed and expected numbers of cancers and their standardized incidence ratios (SIR) and 95\% confidence intervals $(95 \% \mathrm{CI})$ for the deck officers (46 955.0 person-years) in 19661998 , with a 20 -year lag time.

\begin{tabular}{|c|c|c|c|c|}
\hline Cancer sites $^{\text {a }}$ & $\begin{array}{l}\text { Observed } \\
\text { (N) }\end{array}$ & $\begin{array}{l}\text { Expected } \\
\text { (N) }\end{array}$ & SIR & $95 \% \mathrm{Cl}$ \\
\hline Lip (140) & 2 & 4.25 & 0.5 & $0.1-1.7$ \\
\hline Oral cavity (143-144) & 1 & 1.64 & 0.6 & $0.0-3.4$ \\
\hline Pharynx (145-149) & - & 2.01 & 0.0 & .. -0.8 \\
\hline Esophagus (150) & 7 & 7.81 & 0.9 & $0.4-1.8$ \\
\hline Stomach (151) & 38 & 37.22 & 1.0 & $0.7-1.4$ \\
\hline Colon (153) & 31 & 30.37 & 1.0 & $0.7-1.4$ \\
\hline Rectum (154) & 11 & 10.63 & 1.0 & $0.5-1.9$ \\
\hline Liver (155) & 6 & 6.51 & 0.9 & $0.3-2.0$ \\
\hline Pancreas (157) & 17 & 12.18 & 1.4 & $0.8-2.2$ \\
\hline Larynx (161) & 6 & 5.13 & 1.2 & $0.4-2.5$ \\
\hline Lung (162) & 66 & 53.82 & 1.2 & $0.9-1.6$ \\
\hline Prostate (177) & 103 & 91.42 & 1.1 & $0.9-1.4$ \\
\hline Testis (178) & - & 1.46 & 0.0 & .. -2.5 \\
\hline Kidney (180) & 25 & 21.54 & 1.2 & $0.8-1.7$ \\
\hline Other urinary organs (181) & 15 & 29.40 & 0.5 & $0.3-0.8$ \\
\hline Melanoma of skin (190) & 5 & 5.24 & 1.0 & $0.3-2.2$ \\
\hline Other skin (191) & 14 & 10.70 & 1.3 & $0.7-2.2$ \\
\hline Brain (193) & 13 & 10.96 & 1.2 & $0.6-2.0$ \\
\hline Thyroid gland (194) & 9 & 7.86 & 1.1 & $0.5-2.2$ \\
\hline Soft tissue sarcoma (197) & 5 & 2.27 & 2.2 & $0.7-5.1$ \\
\hline Unspecified sites (199) & 6 & 8.93 & 0.7 & $0.2-1.5$ \\
\hline Hodgkin's disease (201) & - & 1.64 & 0.0 & .. -2.2 \\
\hline $\begin{array}{l}\text { Non-Hodgkin's lymphoma } \\
(200,202)\end{array}$ & 6 & 10.66 & 0.6 & $0.2-1.2$ \\
\hline Multiple myeloma (203) & 4 & 5.35 & 0.7 & $0.2-1.9$ \\
\hline Leukemia (204) & 8 & 7.96 & 1.0 & $0.4-2.0$ \\
\hline Other sites & 15 & 10.44 & 1.4 & $0.8-2.4$ \\
\hline All cancers (140-205) & 413 & 400.40 & 1.0 & $0.9-1.1$ \\
\hline
\end{tabular}

a Code of the International Classification of Diseases (7th revision) in parentheses.

on cancer site is the same for the cohort and the comparison group. More than $95 \%$ of the cancers reported to the cancer register have histologically confirmed diagnoses (14).

In previous studies of deck officers, an increased incidence of all cancers was found in Denmark (2) and Sweden (3) but not in Finland (4). The differences between these studies are hardly explained by a difference in the types of ships involved. The Danish and the Swedish cohorts were from censuses $(2,3)$ and thus included officers from both the merchant and the fishing fleets in these countries, while the Finnish cohort was from the files of a pension fund of seamen from the merchant fleet (4).

Among the Finnish deck officers a deficit of lung cancer was found (4), while an excess was found among Swedish deck officers (3). In our study there was a nonsignificantly increased incidence of lung cancer. As no pleural cancer was found in our study, the asbestos exposure of the deck officers may have been low; 
Table 5. Observed and expected numbers of cancers and their standardized incidence ratios (SIR) and 95\% confidence intervals (95\% Cl) for the deck officers in 1966-1998, according to year of birth divided into two categories. (Statistically significant figures are shown bold face.)

\begin{tabular}{|c|c|c|c|c|c|c|c|c|}
\hline \multirow[b]{2}{*}{ Cancer sites ${ }^{a}$} & \multicolumn{4}{|c|}{ Born 1920 and earlier } & \multicolumn{4}{|c|}{ Born 1921 and later } \\
\hline & $\begin{array}{l}\text { Observed } \\
(\mathrm{N})\end{array}$ & $\begin{array}{l}\text { Expected } \\
\text { (N) }\end{array}$ & SIR & $95 \% \mathrm{Cl}$ & $\begin{array}{l}\text { Observed } \\
\text { (N) }\end{array}$ & $\begin{array}{l}\text { Expected } \\
\text { (N) }\end{array}$ & SIR & $95 \% \mathrm{Cl}$ \\
\hline All cancers (140-205) & 209 & 196.98 & 1.1 & $0.9-1.2$ & 227 & 239.32 & 0.9 & $0.8-1.1$ \\
\hline Stomach (151) & 19 & 22.56 & 0.8 & $0.5-1.3$ & 23 & 17.72 & 1.3 & $0.8-1.9$ \\
\hline Colon (153) & 22 & 15.55 & 1.4 & $0.9-2.1$ & 10 & 16.35 & 0.6 & $0.3-1.1$ \\
\hline Pancreas (157) & 8 & 6.90 & 1.2 & $0.5-2.3$ & 9 & 6.13 & 1.5 & $0.7-2.8$ \\
\hline Lung (162) & 29 & 23.77 & 1.2 & $0.8-1.8$ & 38 & 32.93 & 1.2 & $0.8-1.6$ \\
\hline Prostate (177) & 54 & 49.36 & 1.1 & $0.8-1.4$ & 49 & 42.73 & 1.1 & $0.8-1.5$ \\
\hline Testis (178) & - & 0.18 & 0.0 & .. -20.2 & - & 5.36 & 0.0 & .. -0.7 \\
\hline Kidney (180) & 12 & 9.51 & 1.3 & $0.7-2.2$ & 16 & 14.14 & 1.1 & $0.6-1.8$ \\
\hline Other urinary organs (181) & 9 & 13.76 & 0.7 & $0.3-1.2$ & 7 & 17.52 & 0.4 & $0.2-0.8$ \\
\hline Melanoma of skin (190) & 2 & 1.41 & 1.4 & $0.2-5.1$ & 3 & 5.25 & 0.6 & $0.1-1.7$ \\
\hline Other skin (191) & 7 & 6.01 & 1.2 & $0.5-2.4$ & 7 & 5.36 & 1.3 & $0.5-2.7$ \\
\hline Brain (193) & 4 & 3.82 & 1.0 & $0.3-2.7$ & 9 & 10.51 & 0.9 & $0.4-1.6$ \\
\hline Soft tissue sarcoma (197) & 3 & 1.08 & 2.8 & $0.6-8.1$ & 6 & 2.24 & 2.7 & $1.0-5.8$ \\
\hline Non-Hodgkin's lymphoma $(200,202)$ & 2 & 3.56 & 0.6 & $0.1-2.0$ & 4 & 8.73 & 0.5 & $0.1-1.2$ \\
\hline Leukemia (204) & 3 & 3.71 & 0.8 & $0.2-2.4$ & 6 & 6.01 & 1.0 & $0.4-2.2$ \\
\hline
\end{tabular}

a Code of the International Classification of Diseases (7th revision) in parentheses.

however, the excess of mesothelioma among a cohort of Icelandic engine officers was interpreted to be a consequence of such exposure (10). Asbestos exposure on board may have been limited to certain activities.

The high incidence of soft-tissue sarcoma shown by our cohort (SIR 2.7) was similar to that observed for Swedish deck officers (SIR 3.2) (3). Therefore, it seems unlikely that our result was merely a coincidence. However, an excess of this rare cancer was not hypothesized a priori. In recent reviews, soft-tissue sarcoma has been reported to have genetic a predisposition and to be associated with ionizing radiation and exposure to different chemicals, such as phenoxyacetic acids, chlorophenols, thorotrast, vinyl chloride and arsenic, and chronic lymphedema (18). It has been suggested that viruses and the use of snuff or smokeless tobacco may play an etiologic role in this respect (19). In addition, exposure to electromagnetic fields has been mentioned as a risk factor for soft-tissue sarcoma (11). Ionizing radiation and familial factors are unlikely to be involved in this cohort of deck officers. An Italian case-referent study found an association between occupational exposure to benzene, solvents, and chemical agents and soft tissue sarcoma (20). The nine cases of soft-tissue sarcoma in our study differ from those of larger series in the low proportion of cases located in the extremities and also with regard to the high proportion of rhabdomyosarcoma $(18,19)$. It is noteworthy that no excess of soft-tissue sarcoma was found in two other studies of Icelandic seafarers, all seamen (1) or marine engineers (10). The increased incidence of soft-tissue sarcoma was sim- ilar even after the cohort was divided into two parts according to the year of birth (table 5); therefore it seems that there is no generation effect. However, the increased risk of soft-tissue sarcoma in the younger group was statistically significant. For additional knowledge on the etiology of this uncommon cancer, a larger material is needed, for example, in a case-referent study nested in a few Nordic cohorts of deck officers.

The significant deficit of bladder cancer was not explained by the smoking habits of the deck officers. In the Swedish and Finnish studies, a nonsignificant increase in the incidence of bladder cancer was found (3, 4). The decreased incidence of bladder cancer in our study is thus interesting and is furthermore in contrast to the excess of bladder cancer previously found among marine engineers in Iceland (10).

It is not known to us whether chryptorchidism or a history of if excluded persons from the Navigation School. However, if so, the exclusion may explain the decreased incidence of testis cancer found in our study.

Brain cancer, leukemia, and breast cancer were not in excess in our study, although these cancers have been previously related to exposure to electromagnetic fields (11).

The incidence rates of malignant melanoma and other skin cancers were near unity in our study, but, in the Swedish and the Finnish studies, other skin cancers (excluding basal cell carcinomas) were in excess $(3,4)$.

Both the Finnish and Swedish studies on deck officers found an increased risk of alcohol-related cancers (ie, cancer of the mouth, pharynx, esophagus, liver, and 
larynx) $(3,4)$. This excess risk was considered an indication of more frequent use of alcohol among the deck officers than among the general population $(3,4)$. No excess risk of alcohol-related cancer was found in our study.

In conclusion, there is no increased risk of all cancers among deck officers in Iceland, and alcohol- and smoking-related cancers are not more common among deck officers than among the general male population. It is unclear why there is an increased incidence of softtissue sarcoma, but similar results have previously been found in other groups of deck officers, and, therefore, additional studies of this rare cancer type are warranted.

\section{Acknowledgments}

This work was supported in part by the University of Iceland Research Fund and by the Icelandic Research Council (grant 990820099).

\section{References}

1. Rafnsson V, Gunnarsdottir H. Cancer incidence among seamen in Iceland. Am J Ind Med 1995;27:187-93.

2. Brandt LPA, Krik NU, Jensen OC, Hansen HL. Mortality among Danish merchant seamen from 1970 to 1985. Am J Ind Med 1994;25:867-76.

3. Nilsson R. Cancer in seamen with special reference to chemical health hazards [dissertation]. Göteborg: Göteborg University; 1998.

4. Pukkala E, Saarni H. Cancer incidence among Finnish seafarers, 1967-92. Cancer Causes Control 1996;7:231-9.

5. Moen B, Riise T, Helseth A. Cancer amoing captains and mates on Norwegian tankers. APMIS 1990;98:185-90.

6. Selikoff IJ, Lilis R, Levin G. Asbestotic radiological abnormalities among United States merchant marine seamen. Br J Ind Med 1990;47:292-7.
7. Jones RN, Diem JE, Ziskand MM, Rodiguez M, Weill H. Radiographic evidence of asbestos effects in American marine engineers. J Occup Med 1984;26:281-4.

8. Velonakis EG, Tsorva A,Tzonou A, Trichopoulos D. Asbestos related chest $\mathrm{x}$ ray changes in Greek merchant marine seamen. Am J Ind Med 1989;15:511-6.

9. Rafnsson V, Jóhannesdóttir SG, Oddsson H, Benediktsson $\mathrm{H}$, Tulinius H, Magnússon G. Mortality and cancer incidence among marine engineers and machinists in Iceland. Scand J Work Environ Health 1988;14:197-200.

10. Rafnsson V, Sulem P. Cancer incidence among marine engineers, a population based study. Cancer Cause Control 2003;14:29-35.

11. Tynes T, Andersen A, Langmark F. Incidence of cancer in Norwegian workers potentially exposed to electromagnitic fields. Am J Epidemiol 1992;136:81-8.

12. Arnalds ES. Stýrimannaskólinn í Reykjavík í 100 ár [The Navigation School in Reykjavik, 100-year anniversary]. Reykjavik: Örn og Örlygur bókaklúbbur; 1993.

13. Jonsson G, Magnusson MS. Hagskinna. Icelandic historical statistics. Reykjavik: Statistics Iceland; 1997.

14. Tulinius H, Ragnarsson J. Cancer Incidence in Iceland 19551984. Reykjavik: Cancer Society and Director General of Health; 1987.

15. Breslow NE, Day NE. Statistical methods in cancer research; vol. II (The design and analysis of cohort studies). Lyon: International Agency for Research on Cancer; 1987.

16. Tóbaksvarnarnefnd. Reykingar á Íslandi Ársskýrsla 2000 [Smoking habits in Iceland: annual report 2000]. Reykjavík: Pricewaterhouse Coopers ehf; 2000.

17. Axelson O, Steenland K. Indirect methods of assessing the effects of tobacco use in occupational studies. Am J Ind Med 1988;13:105-18.

18. Brennan MF, Casper ES, Harrison LR. Soft tissue sarcoma. In: DeVita VT, Hellman S, Rosenberg SA. Cancer: principle and practice of oncology. Philadelphia (PA): LippincottRaven Publishers; 1997.

19. Hoar Zahm S, Tucker MA, Fraumeni JF Jr. Soft tissue sarcomas. In: Schottenfeld D, Fraumeni JF Jr, editor. Cancer epidemiology and prevention. New York (NY): Oxford University Press; 1996.

20. Serraino D, Franceschi S, La Vecchia C, Carbone A. Occupation and soft tissue sarcoma in northeastern Italy. Cancer Causes Control 1992;3:25-30.

Received for publication: 10 April 2002 